\title{
Accumulation of toxic elements in an invasive crayfish species (Procambarus clarkii) and its health risk assessment to humans
}

\author{
A. Anandkumar ${ }^{\mathrm{a}}, \mathrm{Jian} \mathrm{Li}^{\mathrm{a} 1}, \mathrm{~K}$. Prabakaran ${ }^{\mathrm{a}}$, Zhang Xi Jia ${ }^{\mathrm{a}}$, Zhanrui Leng ${ }^{\mathrm{a}}$, \\ R. Nagarajan ${ }^{\mathrm{b}}$, Daolin $\mathrm{Du}^{\mathrm{a}^{*}}$ \\ a Institute of Environment and Ecology, School of Environment and Safety Engineering, Jiangsu \\ University, Zhenjiang 212013, PR China \\ ${ }^{\mathrm{b}}$ Department of Applied Geology, Faculty of Engineering and Science, Curtin University, Malaysia \\ * Corresponding authors Tel: +8613852946639; Email address: daolindu@ 163.com; \\ anand2explore@gmail.com
}

1 The authors contributed equally to this work. 


\section{Highlights:}

1) Accumulation of elements in P. clarkii tissues was higher compared to M. nipponense species.

2) Zinc accumulation was higher in walking legs of $P$. clarkii species.

3) Mercury concentration was higher in muscle tissues.

4) Studied species can be used as a bioindicator for assessing contamination in YRD.

5) Based on EDI and HI calculation, studied elements will not pose any serious health effects. 


\begin{abstract}
The accumulation and potential health risks of eight trace elements $(\mathrm{Cu}, \mathrm{Cd}, \mathrm{Cr}, \mathrm{Mn}, \mathrm{Zn}$, $\mathrm{Pb}, \mathrm{Hg}$ and $\mathrm{As}$ ) were analyzed in the commercially important crayfish and oriental river prawn species from the Zhenjiang City, Jiangsu Province, China. The accumulation sequence of elements in different tissues were as gill $>$ walking leg $>$ muscle. Among the analyzed elements, majority of the elements were accumulated in the gill tissue, while $\mathrm{Hg}$ was concentrated in abdominal muscle and $\mathrm{Zn}$ in walking leg tissues. The elements $\mathrm{Zn}\left(95.9 \mu \mathrm{g} \mathrm{g}^{-1}\right)$ and $\mathrm{Cd}(0.02 \mu \mathrm{g}$ $\left.\mathrm{g}^{-1}\right)$ were the most and the least accumulated elements in the abdominal muscle tissue. The calculated estimated daily intake (EDI) and hazard indices (HI) of the analyzed elements in the tissue organs of Procambarus clarkii and Macrobrachium nipponense species were lower than the Chinese Food Health Criterion and international guideline values and results in no acute toxicities and thus, safe for human consumption. This study also suggests that Procambarus clarkii species can be used as an effective bio-indicator organism for examining the toxic heavy metals in the freshwater ecosystems.
\end{abstract}

Keyword: Procambarus clarkii, Mercury, Arsenic, Risk Assessment and Bioaccumulation

\title{
1. Introduction
}

Globally, due to rapid increase in the industrialization and urbanization activities, aquatic environments are contaminated with toxic elements and results in adverse health effects to the aquatic biota (Islam and Tanaka 2004). These toxic heavy metals originate from both natural (volcanic eruptions, oceanic hydrothermal vents and geological processes) as well as anthropogenic sources (industries, mining, combustion of coal, deforestation, pesticide usages, municipal and sewage discharges) and enter into the coastal environment through rivers and 
stream channels. The level of toxic and heavy elements are mainly associated with sediments compared to water column, due to the presence of different carriers i.e. organic matter clay minerals and metal oxides in the sediment layers (Zhang et al. 2014; Nagarajan et al. 2019). The heavy metals associated with the sediments can be transferred to water bodies by mobility due to changes in the environmental conditions (i.e. variations in $\mathrm{pH}$, redox potential, and acidification of water column) which can become readily bioavailable to the aquatic organism and be amplified from lower tropical level to higher order in the food chain (Chakraborty et al. 2015; Tiquio et al. 2017; Zhong et al. 2018; Anandkumar et al. 2019). Some elements (Cu and Zn) are required in trace amounts for the growth and metabolic activities of the aquatic organism. However, they show toxic effects at elevated concentrations. Other elements $(\mathrm{Hg}, \mathrm{As}, \mathrm{Cd}$, and $\mathrm{Pb}$ ) are non-essential and exhibit toxic properties, cause cellular damage and decrease the growth rate of aquatic organisms and even cause death in trace levels (Hosseini et al. 2015). Aquatic organisms accumulate trace elements through absorption from the water column in minor amounts and greater quantities through trophic transfer from prey, whereas humans can be exposed via food-chain and results in the cause of acute and chronic health effects (George et al., 2010; Anandkumar et al., 2018).

Aquatic products are rich in protein, omega-3-fatty acid, vitamins, calcium and more nutrients commonly consumed by humans all over the world (Kalantzi et al. 2016; Anandkumar et al. 2018). In order to maintain a healthy diet, the American Heart Association recommends two servings of fish per week (Neff et al. 2014). According to the aquaculture statistical data from the U.N.'s Food and Agricultural Organization (FAO, Rome, Italy), China is one of the major suppliers for aquaculture products across the globe, with a total amount of 62,575 thousand tons, accounting for $37.42 \%$ of the global amount (167,228 thousand tons) in 2014 
(CFGN 2016; FAO 2016). "The production cost of freshwater aquaculture was 581,318 Million Yuan (approximately 89,606 Million Dollars), which accounted for 48.4\% of the total fishery production cost (approximately 185,016 Million Dollars) in 2016" (Zhang et al. 2014; Zhang et al. 2018). China's the biggest and giant freshwater prawn culturing and production region is at near Gaoyou City, Jiangsu Province. Thus, many concerns have been raised on the metal contamination and its accumulation level in the aquatic species consumed as food should be monitored. Hence, monitoring the safety of freshwater aquaculture products from China is very important as it is supplied all over the world and for national population.

The red swamp crayfish, Procambarus clarkii (Girard 1852), is an invasive freshwater species that originated from north-eastern Mexico and in the south-central United States and currently shows a cosmopolitan distribution all over the world (Barbaresi and Gherardi 2000). In 1929, it invaded into China from Japan and now established stable population in all types of freshwater habitats such as rivers, lakes, ponds, streams and paddy fields (Yi et al. 2018). Even though it is an invasive species, it has become one of the favorite aquatic food products in China due to its unique taste and flavored meat. It is one of the most economically important farmed aquatic species in China, as it is cheaper than other protein sources. The annual consumption rate of $P$. clarkii reaches more than 600,000 metric tons during the summer season (April to June) particularly in the cities located along the middle and lower reaches of the Yangtze River system (Yi et al. 2018). The M. nipponense is an indigenous species and distributed throughout China and is farmed on a large scale. This species has high aquaculture potential and it can withstand in low temperatures and bred exclusively in freshwater and commonly available in the lower reaches of the Yangtze River. Crayfish species have been used as a good bio-indicator species to 
determine the toxic metal contamination in the environment by many researchers. It is widely used because of its following characteristics (i) can able to tolerate environmental stress better than other organisms; (ii) have long life spans (2 to 5 years) and low fecundity with high juvenile survival; (iii) ability to survive in physical contact with contaminated water and soil; (iv) occupy higher tropical level in the food chain; (v) huge in size to get samples from different tissue organs, which make them a suitable study specimen for environmental monitoring studies (Alcorlo et al. 2006; Suárez-Serrano et al. 2010; Gedik et al. 2017).

According to McClain et al. (2007) crayfish have been classified as herbivores, detritivores and omnivores, which magnify the metal levels by feeding the contaminated organisms from the lower trophic levels of the food chain. It feeds on detritus, algae, plant matter, aquatic invertebrates, amphibians and fish (Gherardi 2006). Based on the literature survey, it is observed that the sediment and water in the middle and lower reaches of the Yangtze River area is contaminated with the heavy metals (Pan and Wang 2012; Yu et al. 2018; Wang et al. 2019). Water used for the aquaculture practices normally comes from the surrounding river diversion, well water and natural precipitation (Omar et al. 2013). In addition, the intensity of consuming the farmed and cultured aquatic products is rapidly increasing in these areas. However, the toxic element contents in crayfish and other aquatic products collected from the Zhenjiang city is still unknown and the information's available is sparse. Therefore, determination and investigation of toxic elements in the crayfish and its potential health risks due to consumption is extremely important for human health. Thus, the aim of the present work is to investigate the concentrations of toxic elements in different tissue organs of the $P$. clarkii species collected from the Zhenjiang City and to evaluate the potential health risk to humans by comparing with national and international food safety guidelines and other similar studies. 


\section{Materials and Methods}

\subsection{Study Area}

Zhenjiang city lies on the southern banks of the fertile Yangtze River delta in the eastern China of Jiangsu Province. It is the place where the famous Yangtze River and BeijingHangzhou Grand Canal intersect and the city is known for its surrounding hills. The Yangtze River (length $6300 \mathrm{~km}$ ), is the third largest river in the World and the longest river in China and covers 1.80 -million-km² ${ }^{2}$ and it has 996 billion cubic meters of total water resources (Yi et al. 2011). It is divided into several reaches and is classified as upper, middle and lower reaches. The Zhenjiang city is located in the lower reaches of the Yangtze River. It plays an important role in China's sustainable economic and social development. According to the Yangtze River yearbook, the provinces in the Yangtze River Delta releases the quantity of $\mathrm{Pb}$ and $\mathrm{Cr}$ in sewage was $84.3 \%$ and $68.8 \%$ of China in 2012, respectively (YRYCC 2013). The majority of solid waste and a tremendous amount of wastewater were discharged into the Yangtze River which particularly affects the ecology of the river at middle and lower reaches and results in long term impacts on aquatic habitats and humans (Song et al. 2011; Liu et al. 2019). The Zhenjiang city has been developed with various commercial and residential areas, riverside parks, industries, transportation networks and tourism sectors. It also has an important port in the navigation along the Yangtze River. The local annual mean temperature is $15.5^{\circ} \mathrm{C}$ and has four obvious seasons (spring, summer, autumn and winter). The hottest and coldest months in the region are July and January respectively. The annual average rainfall is $1088.2 \mathrm{~mm}$, most of which occurs in the summer and autumn season.

\subsection{Sample collection and processing}


The red swamp crayfish, Procambarus clarkii, and the oriental river prawn Macrobrachium nipponense were collected for the present study. From each species, a minimum of 30 specimens were collected from a local fish market near Jiangsu University, a famous place for the selling of live fishery products from the catchment area of the Yangtze River basin (Fig. 1). Collected aquatic organisms were packed in polyethylene bags, labeled, placed in an ice box and transferred to the laboratory for analysis. Their average length and weight, scientific and common names, habitat, and the feeding habits were recorded before they were freezed for further analysis and the details are reported in Table 1. Later, the freezed samples were thawed at room temperature, and washed with distilled water. Crayfish samples were dissected into abdominal muscle tissues, walking legs and gills. Due to its small size (maximum $8 \mathrm{~cm}$ ) the whole body tissue of the oriental river prawn is used for analysis. The exoskeletons were removed before drying. All these tissues were dried at $80^{\circ} \mathrm{C}$ up to complete dryness. The water content of the tissue samples were calculated based on the difference between the initial wet weight and final dry weights. The dried tissue samples were powdered using an agate mortar and the grinded samples were stored in plastic containers and were placed in the desiccator until further analysis. The metals' concentrations of the analyzed aquatic samples are expressed in $\mu \mathrm{g} / \mathrm{g}$ (dry weight).

\subsection{Digestion of Aquatic Organisms}

The dried powdered tissue were thoroughly homogenized and then subjected to digestion using concentrated nitric acid and hydrogen peroxide (1:1) according to FAO methods (Daziel and Baker 1983) as described in Anandkumar et al. (2019). Finally the digested samples were analyzed in the Flame Atomic Absorption Spectrometer (FAAS) (Analytik Jena Contr AA300) and Inductively Coupled Plasma Mass Spectrometer (ICP-MS) (Thermo Scientific Xseries 2). 
$\mathrm{Cu}, \mathrm{Zn}$ and $\mathrm{Mn}$ of all digested samples were determined by FAAS, and $\mathrm{Cr}, \mathrm{Cd}, \mathrm{Pb}, \mathrm{Hg}$ and $\mathrm{As}$ were determined by ICP-MS. All chemical reagents used during the analysis were of analytical grade and deionized water was used throughout the study. To avoid possible contamination, all glasswares were soaked in diluted nitric acid for $24 \mathrm{~h}$ and rinsed with distilled water before use. The instrument was calibrated with chemical standard solutions prepared from the stock solution of metals (Sinopharm Chemical Reagent Co. Ltd, Shanghai). As a part of quality assurance, a quality control sample was run at a frequency of every five samples. Blanks and calibration standard solutions were also analyzed. The precision of the analytical performance was validated by measuring the certified standard reference material (TORT-2, National Research Council, Canada). The overall mean recovery rates for trace elements ranged between $87 \%$ and $105 \%$, and this was found to be satisfactory with the results of certified values.

\subsection{Bioaccumulation Factor (BAF)}

The BAF values of the selected trace elements in the edible muscle tissue were calculated using the following equation (Gobas et al. 2009; George et al. 2011).

$$
B A F=\frac{C m}{C w}
$$

Where, $C_{m}$ is the mean concentration of element in muscle tissues $\left(\mathrm{mg} / \mathrm{kg}\right.$ dry wt) and $\mathrm{C}_{\mathrm{w}}$ is the mean concentration of the same element in the water $(\mu \mathrm{g} / \mathrm{l})$, which was adopted from Yi et al. (2011). (Anandkumar 2016)

\subsection{Calculation of Estimated Daily Intake (EDI)}

The EDT values were calculated by considering the geometric mean concentration of the metals in $\mathrm{mg} \mathrm{kg}^{-1}$ (wet weight) and per day consumption. The average daily aquatic products consumption for the Chinese population is $32.73 \mathrm{~g}$ per capita per day (EFH 2013), as reported by 
the National Bureau of Statistics of China (CSY 2016). People who live in coastal area of China would eat $105 \mathrm{~g}$ fish and crayfish per day (Jiang et al. 2005), and people living in the Yangtze River basin would consume the same dose just like the coastal area of China (Yi et al. 2017). The estimated daily intake of metals was calculated according to (Song et al. 2009; Giri and Singh 2015; Anandkumar et al. 2019).

$$
\mathrm{EDI}=\frac{C_{\text {metal }} \times \text { Cons }}{B_{w}}
$$

Where EDI characterizes the estimated daily intake of metal through the consumption of aquatic organism for an adult ( $\mu \mathrm{g} \mathrm{Kg} \mathrm{Kg}^{-1} /$ day); $\mathrm{C}_{\text {metal }}$ is the concentration of metal in biological samples $(\mu \mathrm{g}$ $\mathrm{Kg}^{-1}$ ) wet weight; Cons signifies the day-to-day consumption rate (g/day), wet weight; $\mathrm{B}_{\mathrm{w}}$ is the body weight $(\mathrm{Kg})$ of an adult. The average body weight was $(70 \mathrm{~kg})$ for Chinese adults (Liu et al. 2018).

\section{Results}

The average concentrations of trace/heavy elements $(\mathrm{Cu}, \mathrm{Cd}, \mathrm{Cr}, \mathrm{Zn}, \mathrm{Mn}, \mathrm{Pb}, \mathrm{Hg}$ and $\mathrm{As})$ in the most commonly consumed and commercially available red swamp crayfish and the oriental river prawn species were analyzed in their different tissue organs. Among the eight elements studied $\mathrm{Cu}, \mathrm{Zn}$ and $\mathrm{Mn}$ are essential and required in tiny amounts for the organisms; while $\mathrm{Cr}, \mathrm{Pb}, \mathrm{Cd}, \mathrm{Hg}$ and $\mathrm{As}$ are non-essential and toxic even at low concentration. The order of elemental accumulation in different organ tissues of analyzed species is presented in Table 2. The average concentration of elements in $P$. clarkii, and $M$. nipponense species are presented in the Table 3, with the average concentrations reported for the similar species from the other literatures.

In the present study, the observed $\mathrm{Cu}$ concentration in $P$. clarkii, and $M$. nipponense species was in the range of $17.3 \mu \mathrm{g} \mathrm{g}^{-1}$ to $93.8 \mu \mathrm{g} \mathrm{g}^{-1}$ with an average of $50.2 \pm 54.1 \mu \mathrm{g} \mathrm{g}^{-1}$. The 
highest $\mathrm{Cu}$ concentration was observed in the gills followed by walking legs and abdominal muscles of $P$. clarkii species. The highest $\mathrm{Zn}$ accumulation was observed in the walking legs followed by the abdominal muscles and gills. Significant difference in the accumulation level was observed in the different organs of the same species. $\mathrm{Zn}$ concentration was recorded higher compared to the other elements analyzed in both species. The Zn concentration in all organs varied between 53.9 and $299 \mu \mathrm{g} \mathrm{g}^{-1}$ with an average of $133 \pm 173 \mu \mathrm{g} \mathrm{g} \mathrm{g}^{-1}$. Chromium concentration was higher in gill tissues of $P$. clarkii sp followed by abdominal muscles and walking legs. The $\mathrm{Cr}$ concentration in the present study was in the range of 0.64 to $3.3 \mu \mathrm{g} \mathrm{g}^{-1}$ with an average of $1.4 \pm 1.8 \mu \mathrm{g} \mathrm{g}^{-1}$.

Among the two species analyzed, the highest concentration of Mn was observed in the gill tissues of $P$. clarkii sp followed by walking leg and abdominal muscle tissues. The lowest concentration was observed in the muscle tissues of oriental river prawn M. nipponense species. The Mn concentration in the analyzed aquatic species was in the range of 10.6 to $99.8 \mu \mathrm{g} \mathrm{g}^{-1}$ with an average of $43.4 \pm 63.1 \mu \mathrm{g} \mathrm{g}^{-1}$. The observed $\mathrm{Pb}$ concentration in P. clarkii, and $M$. nipponense species was in the range of 0.0041 to $2.3 \mu \mathrm{g} \mathrm{g}^{-1}$. The highest $\mathrm{Pb}$ accumulation was observed in the gill tissues followed by abdominal muscles and walking leg. Among the elements analyzed, $\mathrm{Pb}$ was the least accumulated metal in the walking leg tissues of $P$. clarkii species. The average $\mathrm{Pb}$ concentration in the present study was $0.7 \pm 1.6 \mu \mathrm{g} \mathrm{g}^{-1}$. The $\mathrm{Cd}$ concentration in the tissue organs of studied aquatic species varied between 0.0063 to $0.0785 \mu \mathrm{g}$ $\mathrm{g}^{-1}$. Maximum concentration of $\mathrm{Cd}$ was observed in the muscle tissues of the oriental river prawn (M. nipponense) species. Higher concentration of $\mathrm{Cd}$ in the $P$. clarkii species was observed in the gill tissue followed by abdominal muscles and walking legs. Among the elements analyzed, $\mathrm{Cd}$ was the least accumulated metal in the muscle tissues of $P$. clarkii species. 
Maximum $\mathrm{Hg}$ concentration was recorded in the $P$. clarkii species followed by $M$. nipponense species. Interestingly, higher $\mathrm{Hg}$ accumulation and distribution was observed in the abdominal muscles followed by the walking leg and gills. The $\mathrm{Hg}$ concentration in all organs was in the range of 0.0076 to $0.222 \mu \mathrm{g} \mathrm{g}^{-1}$ with an average of $0.086 \pm 0.15 \mu \mathrm{g} \mathrm{g}^{-1}$. Mercury was the least accumulated metal in the gill tissues of $P$. clarkii species compared to the other analyzed elements. The concentrations of As in crayfish and oriental river prawn species ranged from 1.13 to $3.8 \mu \mathrm{g} \mathrm{g}^{-1}$ with an average of $2.4 \pm 1.9 \mu \mathrm{g} \mathrm{g}^{-1}$. Maximum As accumulation and distribution levels in the crayfish tissues was observed in gill followed by abdominal muscles and walking leg.

The present study results were comparable with the reported values from other parts of the world (Table 3). There were some exceptions with some of the studies reporting lower or higher values than the present study for the same species because of the geological nature and metal bioavailability of the study area. The results were relatively close for some elements $(\mathrm{Cd}$ and $\mathrm{Hg}$ ) or comparatively higher than the obtained data for similar crayfish and oriental river prawn species.

\section{Discussion}

\subsection{Accumulation of elements in different tissue organs}

In the present study, the accumulation of elements $(\mathrm{Cu}, \mathrm{Zn}, \mathrm{Cr}, \mathrm{Pb}, \mathrm{Mn}, \mathrm{Hg}$ and $\mathrm{As})$ in the tissue organs of crayfish $(P$. clarkii) species was higher than the oriental river prawn $(M$. nipponense) species except of $\mathrm{Cd}$. Among the analyzed elements, $\mathrm{Cu}, \mathrm{Mn}, \mathrm{Cr}, \mathrm{Cd}, \mathrm{Pb}$ and $\mathrm{As}$ show higher concentration in the gill tissue; $\mathrm{Hg}$ and $\mathrm{Zn}$ show a higher accumulations in abdominal muscle and walking leg tissues. Results of the present study showed that elements' accumulation and distribution levels in crayfish tissues were in the decreasing order of gills > 
walking leg $>$ abdominal muscles. Many researchers have reported the same accumulation trend for other heavy metals, stating that higher accumulations was observed in gills and hepatopancreas and muscle tissues with the lowest accumulations (Alcorlo et al. 2006; SuárezSerrano et al. 2010; Kuklina et al. 2014; Goretti et al. 2016; Gedik et al. 2017; Annabi et al. 2018; Subotić et al. 2019). Each metal exhibitions a different accumulation pattern depending on their role in crayfish metabolism.

Abdominal muscle tissue is of the most concern and an important measure from a health viewpoint, because it is the most edible part of the aquatic organism and commonly consumed by the humans. An aquatic organism accumulates metals via two routes (i) dietary exposure via the food-chain and (ii) through the gill surface by waterborne exposure (Ptashynski et al. 2002). The bioaccumulation of toxic elements greatly increases in organisms when their threshold values are exceeded in that environment. Zinc and $\mathrm{Cu}$ always occur in higher concentrations in most of the aquatic organisms, and are essential micronutrients required for their normal growth, physiological functions and metabolism (Handy 1996). On the other hand, the non-essential elements like $\mathrm{Cd}, \mathrm{Pb}, \mathrm{Hg}$ and $\mathrm{As}$ are not involved in any type of metabolic activities in the aquatic organisms, their concentrations tend to increase with the increasing concentrations of the elements in the aquatic environments. Zinc is used as an active center for metalloenzymes and activators of other enzyme systems (carbonic anhydrase), while $\mathrm{Cu}$ is an integral part of the respiratory pigment haemocyanin, accounting for the high $\mathrm{Cu}$ levels observed in the hepatopancreas. Due to the fact that these heavy metals are essential, they are subject to strong regulation, being detoxified by metallothioneins (Canli et al. 1997), eliminated by excretion through faeces or urine, and via haemolymph through excretory organs or gills (Arumugam and Ravindranath 1987). 
Generally, crustaceans accumulate some metals in direct proportion to the increase in the bioavailability (direct contact) from surrounding water and via feeding (Anandkumar et al. 2017). However, $P$. clarkii, in the present study, had showed a high level of elemental (Cu, Mn, $\mathrm{Cr}, \mathrm{Cd}, \mathrm{Pb}$ and $\mathrm{As}$ ) accumulation in its gill tissues regardless their abundance in the ambient water and/or sediment with increasing concentration in aquatic environment and exposure time. Gills of the crayfish are in contact to the external medium and are responsible for metal transfer to organism. This could explain the high metal concentration, recorded herein, in this organ. Meyer et al. (1991) has reported that the gills were the principal site for $\mathrm{Cd}$ and $\mathrm{Pb}$ accumulation of the crayfish and the muscles exhibited very low values. El-Assal and Abdel-Meguid (2017) observed the highest concentration of essential and non-essential elements in the gills of crustaceans and suggested that gills readily absorb and transport the metals to the other organs via haemolymph. Moreover, the accumulation of elements $(\mathrm{Cu}, \mathrm{Mn}, \mathrm{Cr}, \mathrm{Cd}, \mathrm{Pb}$ and $\mathrm{As})$ in $P$. clarkii was higher in gills of crayfish than in walking legs and abdominal muscles which can be attributed to the process of filtration of water against the gills and taking up the metals through the body surface. Svobodová et al. (2017) observed that accumulation of toxic metals in the gill tissues of crayfish from two different localities and found the higher concentrations of metals in crayfish collected from the polluted locality compared to the reference site, a less polluted locality. Gills, which are in direct contact with the environment, have a high permeability. Therefore, they are used as a bio-indicator for indicating metal accumulation in organisms as well as to monitor the surrounding water of a particular environment (Alcorlo et al., 2006; Anandkumar et al., 2018).

The accumulations of toxic elements ( $\mathrm{As}, \mathrm{Pb}, \mathrm{Cd}$ and $\mathrm{Hg}$ ) in crayfish muscle, such as hepatopancreas, gill and exoskeleton tissues have been studied by many researchers (Devesa et 
al. 2002; Alcorlo et al. 2006; Kuklina et al. 2014; Gedik et al. 2017). Inorganic As is considered problematic from a health point of view because of its carcinogenic features. The accumulation of As in sediments, agricultural soils, groundwater, contamination of water bodies by run-off and its bioavailability to aquatic organisms are topics of great concern (Flora 2015). Arsenical pesticides are tremendously toxic which implies that As get accumulated in the soils and remain in the soil for decades, transferred to higher topical level in food chain and cause harmful health effects to humans (Rodríguez-Martín et al. 2006). The accumulation of $\mathrm{Hg}$ in P. clarkii tissues organs of the present study is found to be higher in muscle tissues. Similar observation of higher accumulation of $\mathrm{Hg}$ in the abdominal muscle was reported by Kuklina et al. (2014) in crayfish samples collected from the three drinking water reservoirs in Czech Republic. Suárez-Serrano et al. (2010) observed higher concentration of $\mathrm{Hg}$ and $\mathrm{Pb}$ in the muscle tissues of crayfish collected near the contaminated sites of the lower Ebro River and Delta. These results indicate a great potential of $P$. clarkii to bioaccumulate toxic elements, especially $\mathrm{Hg}$, in the proximity of contaminated sediments and hence it has the capacity to transfer the toxic elements to higher trophic levels, meanwhile crayfish is consequently consumed by fish, birds and humans, thus facilitating biomagnification of the heavy metals trough the full trophic web (Simon and Boudou 2001; Coelho et al. 2013; Aquino et al. 2017). Hence, crayfish occupy a central position in the food-web they are considered as a vector for transferring the toxic metals to the top level predators (including human populations) through tropic transfer.

The hepatopancreas plays an important role in metabolism of heavy metals, uptake and contributes to their detoxification and expulsion. Furthermore, essential metals such as $\mathrm{Cu}$ and Zn may also be subject to regulation either by limiting metal uptake at total body concentration level or by involving specific accumulation strategies of the organism, with active excretion from 
the metal excess and/or stored in an inert form (Rainbow 2002). Conversely, $\mathrm{As}, \mathrm{Cd}, \mathrm{Hg}$ and $\mathrm{Pb}$ (non- essential metals) tend to be detoxified by metallothioneins or phosphoric granules and accumulated permanently in the tissues organs, becoming detrimental elements to aquatic organisms (Anderson et al. 1997; Suárez-Serrano et al. 2010).

\subsection{Sources of metals in the Yangtze River}

Adsorption and desorption process controls the mobility and bioavailability of metals in soil (Gedik et al. 2016). Organic matter, Fe and $\mathrm{Al}$ oxides, soil texture, $\mathrm{pH}$ and Oxidation-Redox Potential (ORP) are the most significant factors prevailing elements mobility and release into the overlying water column (Forstner 1985; Chakraborty et al. 2015; Anandkumar et al. 2019). A metal, unlike other pollutants, are non-biodegradable and can accumulate in soils and sediments over longer periods and enters into aquatic organisms via breathing and feeding and affect the top level predators including human (Gedik and Boran 2013). The middle and lower reaches of the Yangtze River are characterized by Paleozoic marine source rocks and Quaternary unconsolidated sediments. The main mineral resources associated with the regional geology are $\mathrm{Cu}, \mathrm{Zn}$ and $\mathrm{Pb}$ (Wang et al. 2018). Several studies have been conducted to examine the levels of heavy metals in the surface sediments of the upper, middle and lower reaches of the Yangtze River (Yi et al. 2011; Yi and Zhang 2012; Wang et al. 2018). According to Yi et al. (2017), Fe and $\mathrm{Cr}$ are derived from the natural lithogenic source and erosion is the main process for these elements to flow from the upper reaches of the Yangtze River to the lower reaches. Many authors have suggested that the elevated levels of $\mathrm{As}, \mathrm{Cu}, \mathrm{Hg}, \mathrm{Pb}, \mathrm{Cd}$ and $\mathrm{Zn}$ concentration in the surface sediments collected from the Yangtze River originates from the industrial pollution, general over-use of agrochemicals and chemical fertilizers and the discharge of municipal sewage (Song et al. 2011; Lin et al. 2002; Liu et al. 2019). In addition, the flushing operation 
caused by flow may not only cause the resuspension of sediment, but also affect the spatial distribution of heavy metals in the sediment from upper to lower reaches of the river.

\subsection{Bioaccumulation of Elements}

An effect of metal concentration in any tropical level of an aquatic organism depends on bioavailability (uptake from the water body) and bioaccumulation (uptake from the food) factors specific to respective metal and taxa (George et al., 2011; Anandkumar 2017). In the water column, uptake of elements by crustaceans depends upon their bioavailability (Carvalho et al. 1999). The range of bioaccumulation factor for the studied species was $6160-33500$ for $\mathrm{Cu}$; 1740-9650 for $\mathrm{Zn}$; 2-1170 for $\mathrm{Pb}$; 15.6-196 for $\mathrm{Cd}$; 489-2520 for $\mathrm{Cr}$; $18.9-555$ for $\mathrm{Hg}$ and 10803880 for As respectively (Table 4). The bioaccumulation factors of $\mathrm{Cu}, \mathrm{Pb}, \mathrm{Cr}$ and $\mathrm{As}$ elements were higher in gill tissues, whereas $\mathrm{Cd}, \mathrm{Hg}$ and $\mathrm{Zn}$ were more in abdominal muscles and walking leg tissues respectively. Generally, the essential elements $(\mathrm{Cu}$ and $\mathrm{Zn})$ exhibit higher bioaccumulation than that of the toxic non-essential elements $(\mathrm{Pb}, \mathrm{Cd}$ and $\mathrm{Hg})$ in both studied species. Similar interpretations of the higher efficiency of essential elements and a lowest occurrence of non-essential metals in the muscles were noticed in the shrimp tissues from the southwest coast of India (George et al. 2011); crustacean species from the Miri coast, Malaysia (Anandkumar et al., 2019) and Zhanjiang, China (Wu and Yang 2011). The bioaccumulation of elements in the aquatic organisms may vary significantly among different species and depends on exposure frequency, absorption and elimination processes (Hashmi et al. 2002). Apart from this, the two influencing characteristics, i.e. exogenous and endogenous factors, which control the bioaccumulation of elements in the aquatic organisms. Exogenous factors are reflected to environmental parameters such as metal bioavailability, temperature and alkalinity of ambient aquatic environments, whereas, endogenous factors include life cycle, habitat, size, gender, 
ecology, physiological efficiency and feeding nature. Hence, due to these various factors the studied species showed different levels of element accumulation.

\subsection{Estimation of daily intake of metals}

An assessment was made between the observed elements in the crayfish and oriental river prawn samples with the reference values, in order to reveal the safe level of consumption for consumers. The possible risks of metals transmitted to human beings are feasibly dependent on the quantity of fishery products consumed by an individual (Kamaruzzaman et al. 2010). The EDI values of studied elements are presented in the Table 5. The results of the corresponding EDI, obtained from the present study through the consumption of analyzed crayfish and oriental river prawn species are fall below the provisional tolerable daily intake (PDTI) suggested by the Joint FAO/WHO Expert Committee on Food Additives (JECFA 1999b). Therefore, it is confirmed that the consumption of these species does not pose any health issues for consumers.

\subsection{Hazard Level}

Among the analyzed elements, $\mathrm{As}, \mathrm{Hg}, \mathrm{Pb}$ and $\mathrm{Cd}$ are classified as non-essential toxic elements, which cause adverse health hazards to organisms and humans. Various national and international agencies such as the China Food and Drug Administration (CFDA); FAO (1983); the WHO (1989b); the EC (2014) and the FSSAI (2015) have recommended maximum permissible limits for human consumption. The food standards for aquatic organisms set by these organizations are in wet weight based concentrations (Table 6). For comparing with food standards, the metal concentrations in the tissues of aquatic organisms in this study (Table 3), needed to be converted into wet weight by dividing them by factors ranging from 4 to 6 (Anandkumar et al., 2019). In this study, overall a factor 4.54 (i.e. $78 \%$ moisture) was adopted. The food standards of crayfish were unavailable, so a comparison of present data with fish was 
done. By using this factor, the derived wet weight based concentrations of $\mathrm{As}, \mathrm{Cu}, \mathrm{Cd}, \mathrm{Cr}, \mathrm{Hg}$, $\mathrm{Mn}, \mathrm{Pb}$ and $\mathrm{Zn}$ in the tissues organs of (P. clarkii and M. nipponense) species from the fresh markets of Zhenjiang City fell below the maximum permissible limits (MPLs) of the Chinese Food Health Criterion CFHC (1994), WHO (1989), FAO (1983), EC (2014) and FSSAI (2015), whereas Mn and As concentrations were slightly above the acceptable level of WHO (1989) and CFHC (1994) in the tissue organs of both species. Further studies are required to determine the source of As either it derives from the residual products used in the agricultural practices or from the lithology exposed in the catchment of the river basin. However, while comparing with the Hong Kong Government regulations (1987) and Food and Agricultural Organization (1983) Mn and As concentrations recorded in the present study are still below the permissible limits. So the examined species in this study were not associated with any chemical hazards in their muscles and safer for human consumption.

\section{Conclusion}

The reported dataset from the present study clearly documents that the gill tissue is the main storage organs for analyzed elements in the $P$. clarkii species followed by walking leg and abdominal muscle tissues. As the gills, which are in direct contact with the surrounding environment, have a high permeability, and accumulate more metal concentrations. Among the analyzed elements, $\mathrm{Zn}$ has accumulated higher, whereas $\mathrm{Cd}$ and $\mathrm{Hg}$ have accumulated at the least level in the muscle tissues of $P$. clarkii and $M$. nipponense species respectively. According to the BAF calculation, the essential elements $(\mathrm{Cu}$ and $\mathrm{Zn})$ accumulated at a higher efficiency than non-essential elements $(\mathrm{Pb}, \mathrm{Cd}$ and $\mathrm{Hg})$ due to exogenous and endogenous factors and bioavailability of elements in the surrounding aquatic environment. Based on the Estimated Daily Intake (EDI) and Hazard Index calculations (HI), the analyzed elements will not pose any 
serious adverse health effects to humans. Compared to the national (CFHC) and international (WHO/FAO) fishery products guidelines the accumulation of elements in the muscle tissues of crayfish and oriental river prawn species were below the maximum permissible limits on wet weight basis with few exceptions and considered safe for human consumption by avoiding the gill tissues because these tissues contains elevated concentration of As and Mn. Since, the crayfish is an invasive species and have the capacity to tolerate high level of metal content compared to the native species. The both analyzed species from the study area can be consumed safely by humans and it can be used as a sentinel species for assessing the heavy metals contamination in freshwater ecosystems and culturing areas.

\section{Conflict of Interest}

The authors declare that there are no conflicts of interest.

\section{Acknowledgements}

This work was supported by the State Key Research Development Program of China (2017YFC1200100), the National Natural Science Foundation of China (31570414, 31800429, 31770446), the Natural Science Foundation of Jiangsu Province (BK20170540). The authors wish to express his gratefulness to the post-doctoral fellowship awarded by the Jiangsu University, Zhenjiang, China. 


\section{References}

Alcorlo, P., M. Otero, M. Crehuet, A. Baltanás, and C. Montes. 2006. "The use of the red swamp crayfish (Procambarus clarkii, Girard) as indicator of the bioavailability of heavy metals in environmental monitoring in the River Guadiamar (SW, Spain)." Science of The Total Environment 366 (1):380390. doi: https://doi.org/10.1016/j.scitotenv.2006.02.023.

Anandkumar, A. 2016.

Anandkumar, A. , R. Nagarajan, K. Prabakaran, H. B. Chua, and R. Rajaram. 2018. "Human health risk assessment and bioaccumulation of trace metals in fish species collected from the Miri coast, Sarawak, Borneo." Marine Pollution Bulletin 133:655-663. doi: https://doi.org/10.1016/j.marpolbul.2018.06.033.

Anandkumar, A., R. Nagarajan, K. Prabakaran, Chua Han Bing, R. Rajaram, J. Li, and D. Du. 2019. "Bioaccumulation of trace metals in the coastal Borneo (Malaysia) and health risk assessment." Marine Pollution Bulletin 145:56-66. doi: https://doi.org/10.1016/j.marpolbul.2019.05.002.

Anandkumar, A., R. Nagarajan, K. Prabakaran, and R. Rajaram. 2017. "Trace metal dynamics and risk assessment in the commercially important marine shrimp species collected from the Miri coast, Sarawak, East Malaysia." Regional Studies in Marine Science 16:79-88. doi: https://doi.org/10.1016/j.rsma.2017.08.007.

Anderson, M. B., P. Reddy, J. E. Preslan, M. Fingerman, J. Bollinger, L. Jolibois, G. Maheshwarudu, and W. J. George. 1997. "Metal Accumulation in Crayfish,Procambarus clarkii,Exposed to a PetroleumContaminated Bayou in Louisiana." Ecotoxicology and Environmental Safety 37 (3):267-272. doi: https://doi.org/10.1006/eesa.1997.1561.

Annabi, A., R. El Mouadeb, and A. Herrel. 2018. "Distinctive accumulation patterns of heavy metals in Sardinella aurita (Clupeidae) and Mugil cephalus (Mugilidae) tissues." Environmental Science and Pollution Research 25 (3):2623-2629. doi: 10.1007/s11356-017-0703-x.

Aquino, L. F. M. C. , R. O. R. Ribeiro, J. S. Simoes, S. B. Mano, E. T. Mársico, and C. A. Conte Junior. 2017. "Mercury content in whey protein and potential risk for human health." Journal of Food Composition and Analysis 59:141-144. doi: https://doi.org/10.1016/i.jfca.2017.02.014.

Arumugam, M., and M. H. Ravindranath. 1987. "Copper toxicity in the crab,Scylla serrata, copper levels in tissues and regulation after exposure to a copper-rich medium." Bulletin of Environmental Contamination and Toxicology 39 (4):708-715. doi: 10.1007/bf01698466.

Barbaresi, S., and F. Gherardi. 2000. "The Invasion of the Alien Crayfish Procambarus Clarkii in Europe, with Particular Reference to Italy." Biological Invasions 2 (3):259-264. doi: 10.1023/a:1010009701606.

Bhupander, K., and D. P. Mukherjee. 2011. "Assessment of human health risk for arsenic, copper, nickel, mercury and zinc in fish collected from tropical wetlands in India." Advances in Life Science and Technology 2:13-24.

Canli, M., R. M. Stagg, and G. Rodger. 1997. "The induction of metallothionein in tissues of the Norway lobster Nephrops norvegicus following exposure to cadmium, copper and zinc: The relationships between metallothionein and the metals." Environmental Pollution 96 (3):343-350. doi: https://doi.org/10.1016/S0269-7491(97)00043-2.

Carvalho, R. A., M. C. Benfield, and P. H. Santschi. 1999. "Comparative bioaccumulation studies of colloidally complexed and free-ionic heavy metals in juvenile brown shrimp Penaeus aztecus (Crustacea: Decapoda: Penaeidae)." Limnology and Oceanography 44 (2):403-414. doi: 10.4319/lo.1999.44.2.0403.

CFGN. 2016. "China Fishery Government Network. National Fisheries Statistics Bulletin 2017 (In Chinese)." accessed 11 July 2019. http://www.moa.gov.cn/sjzz/yzjzw/yyywyzj/201707/t20170725 5759859.htm. 
CFHC. 1994. Chinese Food Health Criterion. GB 15201-94 for Cd, GB 15199-94 for Cu, GB 14935-94 for $\mathrm{Pb}$ and GB 13106-91 for Zn. Minstry of Health of People's Republic of China.

Chakraborty, Parthasarathi, Darwin Ramteke, and Sucharita Chakraborty. 2015. "Geochemical partitioning of $\mathrm{Cu}$ and $\mathrm{Ni}$ in mangrove sediments: Relationships with their bioavailability." Marine Pollution Bulletin 93 (1):194-201. doi: https://doi.org/10.1016/j.marpolbul.2015.01.016.

Coelho, J. P., C. L. Mieiro, E. Pereira, A. C. Duarte, and M. A. Pardal. 2013. "Mercury biomagnification in a contaminated estuary food web: Effects of age and trophic position using stable isotope analyses." Marine Pollution Bulletin 69 (1):110-115. doi: https://doi.org/10.1016/j.marpolbul.2013.01.021.

CSY. 2016. China Statistical Yearbook. National Bureau of Statistics PRC. China Statistics Press. Beijing.

Daziel, J., and C. Baker. 1983. "Analytical methods for measuring metals by atomic absorption spectrometry." FAO Fish Tech 212:14-21.

Devesa, V., M. A. Súñer, V. W.-M. Lai, S. C. R. Granchinho, J. M. Martínez, D. Vélez, W. R. Cullen, and R. Montoro. 2002. "Determination of arsenic species in a freshwater crustacean Procambarus clarkii." Applied Organometallic Chemistry 16 (3):123-132. doi: 10.1002/aoc.269.

EC. 2014. Commission Regulation. No 488/2014 of 12 May 2014 Amending Regulation (EC) No 1881/2006 As Regards Maximum Levels of Cadmium in Foodstuffs.

EFH. 2013. Exposure factors handbook of Chinese population. China Environmental Press (in Chinese). Beijing.

FAO. 1983. Compilation of Legal Limits for Hazardous Substance in Fish and Fishery Products.

FAO. 2016. Fishery and Aquaculture Statistics for 2014; Food and Agriculture Organization. Rome, Italy.

Flora, S. J. S. 2015. "Arsenic: Chemistry, Occurrence, and Exposure." In Handbook of Arsenic Toxicology, edited by S. J. S. Flora, 1-49. Oxford: Academic Press.

Forstner, U. 1985. Chemical forms and reactivities of metals in sediments. Edited by R. Leschber, R.D. Davis and R. L. Hermite, Chemical methods for assessing bio-available metals in sludges and soils. London: Elsevier Applied Science.

FSSAI. 2015. Food, Safety, Standards Authority of India (FSSAI). Proposes Standard Limits of Metal Contaminants in New Food Articles.

Gedik, K., and M. Boran. 2013. "Assessment of Metal Accumulation and Ecological Risk Around Rize Harbor, Turkey (Southeast Black Sea) Affected by Copper Ore Loading Operations by Using Different Sediment Indexes." Bulletin of Environmental Contamination and Toxicology 90 (2):176-181. doi: 10.1007/s00128-012-0894-2.

Gedik, K., M. Kongchum, M. Boran, and R. D. Delaune. 2016. "Adsorption and desorption of arsenate in Louisiana rice soils." Archives of Agronomy and Soil Science 62 (6):856-864. doi: 10.1080/03650340.2015.1096015.

Gedik, K., M. Kongchum, R. D. DeLaune, and J. J. Sonnier. 2017. "Distribution of arsenic and other metals in crayfish tissues (Procambarus clarkii) under different production practices." Science of The Total Environment 574:322-331. doi: https://doi.org/10.1016/i.scitotenv.2016.09.060.

George, R., S. C. Hsu, S. M. Nair, G. D. Martin, and K. K. C. Nair. 2011. "Trace Metal Dynamics in Marine Shrimps from the Southwest Coast of India." Environmental Forensics 12 (2):162-172. doi: 10.1080/15275922.2011.574313.

Gherardi, F. 2006. "Crayfish invading Europe: the case study of Procambarus clarkii." Marine and Freshwater Behaviour and Physiology 39 (3):175-191. doi: 10.1080/10236240600869702.

Giri, S., and A. K. Singh. 2015. "Metals in Some Edible Fish and Shrimp Species Collected in Dry Season from Subarnarekha River, India." Bulletin of Environmental Contamination and Toxicology 95 (2):226-233. doi: 10.1007/s00128-015-1573-x. 
Gobas, F. A. P. C., W. de Wolf, L. P. Burkhard, E. Verbruggen, and K. Plotzke. 2009. "Revisiting bioaccumulation criteria for POPs and PBT assessments." Integrated Environmental Assessment and Management 5 (4):624-637.

Goretti, E., M. Pallottini, M. I. Ricciarini, R. Selvaggi, and D. Cappelletti. 2016. "Heavy metals bioaccumulation in selected tissues of red swamp crayfish: An easy tool for monitoring environmental contamination levels." Science of The Total Environment 559:339-346. doi: https://doi.org/10.1016/j.scitotenv.2016.03.169.

Handy, R.D. 1996. "Dietary exposure to toxic metals in fish." Seminar Series-Society for Experimental Biology.

Hashmi, M. I., S. Mustafa, and S. A. Tariq. 2002. "Heavy metal concentrations in water and tiger prawn (Penaeus monodon) from grow-out farms in Sabah, North Borneo." Food Chemistry 79 (2):151156. doi: https://doi.org/10.1016/S0308-8146(02)00123-1.

HKG. 1987. Hong Kong Government. Food Adulteration (Metallic Con-tamination) Regulations. Laws of Hong Kong 2, Chapter 132. .

Hosseini, M., S.M. B. Nabavi, S. N. Nabavi, and N. A. Pour. 2015. "Heavy metals (Cd, Co, Cu, Ni, Pb, Fe, and $\mathrm{Hg}$ ) content in four fish commonly consumed in Iran: risk assessment for the consumers." Environmental Monitoring and Assessment 187 (5):237. doi: 10.1007/s10661-015-4464-z.

Islam, S. M., and M. Tanaka. 2004. "Impacts of pollution on coastal and marine ecosystems including coastal and marine fisheries and approach for management: a review and synthesis." Marine Pollution Bulletin 48 (7):624-649. doi: https://doi.org/10.1016/j.marpolbul.2003.12.004.

JECFA. 1999a. Joint FAO/WHO Expert Committee on Food Additives. Reports of the 53rd meeting of the Joint FAO/WHO Expert Committee on Food Additives (JECFA). JECFA/53/TRS. Rome, Italy: Food \& Agriculture Organisation.

JECFA. 1999b. Joint FAO/WHO Expert Committee on Food Additives. Summary and conclusions of the 53rd meeting of the Joint FAO/WHO Expert Committee on Food Additives (JECFA). JECFA/53/SC. Rome, Italy: JECFA/53/SC. Rome, Italy.

Jiang, Q. T., T. K. M. Lee, K. Chen, H. L. Wong, J. S. Zheng, J. P. Giesy, K. K. W. Lo, N. Yamashita, and P. K. S. Lam. 2005. "Human health risk assessment of organochlorines associated with fish consumption in a coastal city in China." Environmental Pollution 136 (1):155-165. doi: https://doi.org/10.1016/i.envpol.2004.09.028.

Kalantzi, I., S. A. Pergantis, K. D. Black, T. M. Shimmield, N. Papageorgiou, M. Tsapakis, and I. Karakassis. 2016. "Metals in tissues of seabass and seabream reared in sites with oxic and anoxic substrata and risk assessment for consumers." Food Chemistry 194:659-670. doi: https://doi.org/10.1016/j.foodchem.2015.08.072.

Kamaruzzaman, B.Y., M.C. Ong, S.Z. Rina, and B. Joseph. 2010. "Levels of some heavy metals in fishes from Pahang river estuary, Pahang, Malaysia." Journal of Biological Sciences 10 (2):157-161.

Kuklina, I., A. Kouba, M. Buřič, I. Horká, Z. Ďuriš, and P. Kozák. 2014. "Accumulation of heavy metals in crayfish and fish from selected Czech reservoirs." BioMed Research International 2014. doi: https://doi.org/10.1155/2014/306103.

Lin, S., I. J. Hsieh, K. Huang, and C. Wang. 2002. "Influence of the Yangtze River and grain size on the spatial variations of heavy metals and organic carbon in the East China Sea continental shelf sediments." Chemical Geology 182 (2):377-394. doi: https://doi.org/10.1016/S00092541(01)00331-X.

Liu, H., G. Liu, S. Wang, C. Zhou, Z. Yuan, and C. Da. 2018. "Distribution of heavy metals, stable isotope ratios $(\delta 13 \mathrm{C}$ and $\delta 15 \mathrm{~N}$ ) and risk assessment of fish from the Yellow River Estuary, China." Chemosphere 208:731-739. doi: https://doi.org/10.1016/i.chemosphere.2018.06.028. 
Liu, M., J. Chen, X. Sun, Z. Hu, and D. Fan. 2019. "Accumulation and transformation of heavy metals in surface sediments from the Yangtze River estuary to the East China Sea shelf." Environmental Pollution 245:111-121. doi: https://doi.org/10.1016/i.envpol.2018.10.128.

McClain, W.R., R.P. Romaire, C.G. Lutz, and M.G. Shirley. 2007. "Louisiana crawfish production manual." Louisiana State University Agriculture Centre, accessed 10 July 2019. https://articles.extension.org/sites/default/files/w/9/9c/Louisiana Crawfish Production Manu al.pdf.

Meyer, W., M. Kretschmer, A. Hoffmann, and G. Harisch. 1991. "Biochemical and histochemical observations on effects of low-level heavy metal load (lead, cadmium) in different organ systems of the freshwater crayfish, Astacus astacus L. (crustacea: Decapoda)." Ecotoxicology and Environmental Safety 21 (2):137-156. doi: https://doi.org/10.1016/0147-6513(91)90016-I.

Mortimer, C. M., and M. Cox. 1999. Contaminants in oysters and crabs in a canal adjacent to Lae Drive, runaway bay, Queensland. Report of a study conducted for gold coast city council. Queensland. Brisbane, Australia.

Nagarajan, R., A. Anandkumar, S. M. Hussain, M. P. Jonathan, Mu Ramkumar, S. Eswaramoorthi, A. Saptoro, and H. B. Chua. 2019. "Chapter 12 - Geochemical Characterization of Beach Sediments of Miri, NW Borneo, SE Asia: Implications on Provenance, Weathering Intensity, and Assessment of Coastal Environmental Status." In Coastal Zone Management, edited by Mu Ramkumar, R. Arthur James, David Menier and K. Kumaraswamy, 279-330. Elsevier.

Neff, M. R., S. P. Bhavsar, F. J. Ni, D. O. Carpenter, K. Drouillard, A.T. Fisk, and M. T. Arts. 2014. "Riskbenefit of consuming Lake Erie fish." Environmental Research 134:57-65. doi: https://doi.org/10.1016/j.envres.2014.05.025.

Omar, W. A., K. H. Zaghloul, A. A. Abdel-Khalek, and S. Abo-Hegab. 2013. "Risk Assessment and Toxic Effects of Metal Pollution in Two Cultured and Wild Fish Species from Highly Degraded Aquatic Habitats." Archives of Environmental Contamination and Toxicology 65 (4):753-764. doi: 10.1007/s00244-013-9935-z.

Pan, K., and W. X. Wang. 2012. "Trace metal contamination in estuarine and coastal environments in China." Science of The Total Environment 421-422:3-16. doi: https://doi.org/10.1016/i.scitotenv.2011.03.013.

Ptashynski, M. D., R. M. Pedlar, R. E. Evans, C. L. Baron, and J. F. Klaverkamp. 2002. "Toxicology of dietary nickel in lake whitefish (Coregonus clupeaformis)." Aquatic Toxicology 58 (3):229-247. doi: https://doi.org/10.1016/S0166-445X(01)00239-9.

Rainbow, P. S. 2002. "Trace metal concentrations in aquatic invertebrates: why and so what?" Environmental Pollution 120 (3):497-507. doi: https://doi.org/10.1016/S0269-7491(02)00238-5.

Rodríguez-Martín, J.M., M.L. Arias, and J. M. Grau-Corbí. 2006. "Heavy metals contents in agricultural topsoils in the Ebro basin (Spain). Application of the multivariate geoestatistical methods to study spatial variations." Environmental Pollution (Barking, Essex : 1987) 144 (3):1001-1012. doi: 10.1016/j.envpol.2006.01.045.

Simon, O., and A. Boudou. 2001. "Simultaneous experimental study of direct and direct plus trophic contamination of the crayfish astacus astacus by inorganic mercury and methylmercury." Environmental Toxicology and Chemistry 20 (6):1206-1215. doi: 10.1002/etc.5620200609.

Song, B., M. Lei, T. Chen, Y. Zheng, Y. Xie, X. Li, and D. Gao. 2009. "Assessing the health risk of heavy metals in vegetables to the general population in Beijing, China." Journal of Environmental Sciences 21 (12):1702-1709. doi: https://doi.org/10.1016/S1001-0742(08)62476-6.

Song, Y., J. Ji, Z. Yang, X. Yuan, C. Mao, R. L. Frost, and G. A. Ayoko. 2011. "Geochemical behavior assessment and apportionment of heavy metal contaminants in the bottom sediments of lower reach of Changjiang River." CATENA 85 (1):73-81. doi:

https://doi.org/10.1016/j.catena.2010.12.009. 
Suárez-Serrano, A., C. Alcaraz, C. Ibáñez, R. Trobajo, and C. Barata. 2010. "Procambarus clarkii as a bioindicator of heavy metal pollution sources in the lower Ebro River and Delta." Ecotoxicology and Environmental Safety 73 (3):280-286. doi: https://doi.org/10.1016/i.ecoenv.2009.11.001.

Subotić, S., Ž. Višnjić-Jeftić, V. Đikanović, S. Spasić, J. Krpo-Ćetković, and M. Lenhardt. 2019. "Metal Accumulation in Muscle and Liver of the Common Nase (Chondrostoma nasus) and Vimba Bream (Vimbavimba) from the Danube River, Serbia: Bioindicative Aspects." Bulletin of Environmental Contamination and Toxicology 103 (2):261-266. doi: 10.1007/s00128-019-026573.

Svobodová, J., K. Douda, D. Fischer, N. Lapšanská, and P. Vlach. 2017. "Toxic and heavy metals as a cause of crayfish mass mortality from acidified headwater streams." Ecotoxicology 26 (2):261-270. doi: 10.1007/s10646-017-1760-0.

Tiquio, M.G. J., C. Hurel, N. Marmier, M. Taneez, B. Andral, N. Jordan, and P. Francour. 2017. "Sedimentbound trace metals in Golfe-Juan Bay, northwestern Mediterranean: Distribution, availability and toxicity." Marine Pollution Bulletin 118 (1):427-436. doi: https://doi.org/10.1016/j.marpolbul.2017.02.065.

USEPA. 2000. Guidance for Assessing Chemical Contaminant Data for Use in Fish Advisories, Risk Assessment and Fish Consumption Limit. Washington, DC, USA: Office of Science and Technology and Office of Water.

Wang, H., X. Ran, J. Li, J. Liu, W. Wu, M. Li, and J. Zang. 2019. "Response of the sediment geochemistry of the Changjiang River (Yangtze River) to the impoundment of the Three Gorges Dam." Journal of Environmental Sciences 83:161-173. doi: https://doi.org/10.1016/j.jes.2019.04.003.

Wang, H., Q. Wu, W. Hu, B. Huang, L. Dong, and G. Liu. 2018. "Using multi-medium factors analysis to assess heavy metal health risks along the Yangtze River in Nanjing, Southeast China." Environmental Pollution 243:1047-1056. doi: https://doi.org/10.1016/i.envpol.2018.09.036.

WHO. 1989a. Heavy metals environmental aspects. Environmental Health Criteria. Geneva, Switzerland.

WHO. 1989b. WHO, 1989. Heavy Metals Environmental Aspects. Environmental Health Criteria. Geneva, Switzerland.

$\mathrm{Wu}, \mathrm{X}$. Y., and Y. F. Yang. 2011. "Heavy metal (Pb, Co, Cd, Cr, Cu, Fe, Mn and $\mathrm{Zn}$ ) concentrations in harvest-size white shrimp Litopenaeus vannamei tissues from aquaculture and wild source." Journal of Food Composition and Analysis 24 (1):62-65. doi: https://doi.org/10.1016/j.jfca.2010.03.030.

Yi, S., Y. Li, L. Shi, L. Zhang, Q. Li, and J. Chen. 2018. "Characterization of Population Genetic Structure of red swamp crayfish, Procambarus clarkii, in China." Scientific Reports 8 (1):5586. doi: 10.1038/s41598-018-23986-z.

Yi, Y. J., C. Tang, Ti. Yi, Z. Yang, and S. H. Zhang. 2017. "Health risk assessment of heavy metals in fish and accumulation patterns in food web in the upper Yangtze River, China." Ecotoxicology and Environmental Safety 145:295-302. doi: https://doi.org/10.1016/j.ecoenv.2017.07.022.

$\mathrm{Yi}, \mathrm{Y}$. J., and S. H. Zhang. 2012. "Heavy metal (Cd, Cr, Cu, Hg, Pb, Zn) concentrations in seven fish species in relation to fish size and location along the Yangtze River." Environmental Science and Pollution Research 19 (9):3989-3996. doi: 10.1007/s11356-012-0840-1.

Yi, Y., Z. Yang, and S. Zhang. 2011. "Ecological risk assessment of heavy metals in sediment and human health risk assessment of heavy metals in fishes in the middle and lower reaches of the Yangtze River basin." Environmental Pollution 159 (10):2575-2585. doi: https://doi.org/10.1016/i.envpol.2011.06.011.

YRYCC. 2013. Yangtze River Yearbook Compile Committee In Yangtze River Yearbook. Yangtze River Yearbook Society of Changjiang Water Resources.

Yu, L., C. Song, C. Zhang, L. Fan, L. Qiu, W. Wu, S. Meng, G. Hu, and J. Chen. 2018. "Occurrence of sulfonamides in fish in the lower reaches of Yangtze River, China and estimated daily intake for 
understanding human dietary exposure." Aquaculture 495:538-544. doi: https://doi.org/10.1016/j.aquaculture.2018.06.033.

Zhang, J., L. Zhu, F. Li, C. Liu, Z. Qiu, M. Xiao, and Y. Cai. 2018. "Comparison of Toxic Metal Distribution Characteristics and Health Risk between Cultured and Wild Fish Captured from Honghu City, China." International Journal of Environmental Research and Public Health 15 (2):334.

Zhang, L., D. Zhang, Y. Wei, L. Luo, and T. Dai. 2014. "Risk assessment of trace elements in cultured freshwater fishes from Jiangxi province, China." Environmental Monitoring and Assessment 186 (4):2185-2194. doi: 10.1007/s10661-013-3528-1.

Zhong, W., Y. Zhang, Zi. Wu, R. Yang, X. Chen, J. Yang, and L. Zhu. 2018. "Health risk assessment of heavy metals in freshwater fish in the central and eastern North China." Ecotoxicology and Environmental Safety 157:343-349. doi: https://doi.org/10.1016/j.ecoenv.2018.03.048. 
Table 1. Morphometric measures of the studied crayfish and oriental river prawn species from the Zhenjiang city

\begin{tabular}{|l|c|c|c|c|c|c|}
\hline \multicolumn{1}{|c|}{ Species } & $\begin{array}{c}\text { English/ } \\
\text { Chinese name }\end{array}$ & $\begin{array}{c}\text { Length } \\
\text { (cm) }\end{array}$ & $\begin{array}{c}\text { Weight } \\
\text { (g) }\end{array}$ & Habitat & Feeding nature & Climate \\
\hline Procambarus clarkii & $\begin{array}{c}\text { Crayfish/ } \\
\text { 小龙虾 }\end{array}$ & 8.6 & 21.5 & Benthic & $\begin{array}{c}\text { Omnivores (algae, molluscs, worms, } \\
\text { other crustaceans, fungi, bacteria and } \\
\text { detritus) }\end{array}$ & Tropical \\
$\&$ \\
$\begin{array}{l}\text { Macrobrachium } \\
\text { nipponense }\end{array}$ & $\begin{array}{c}\text { Oriental River } \\
\text { prawn/ } \\
\text { 在东方河虾 }\end{array}$ & 6.03 & 3.33 & Benthic & $\begin{array}{c}\text { Omnivores (algae, molluscs, worms, } \\
\text { other crustaceans, fungi, bacteria and } \\
\text { detritus) }\end{array}$ & $\begin{array}{c}\text { Sub- } \\
\text { tropical }\end{array}$ \\
\hline
\end{tabular}

Table 2. Elements accumulation in different organs of the Crayfish and Oriental River prawn.

\begin{tabular}{|l|l|l|}
\hline \multicolumn{1}{|c|}{ Species } & \multicolumn{1}{|c|}{ Tissue } & \multicolumn{1}{c|}{ Order } \\
\hline \multirow{2}{*}{ Procambarus clarkii } & Abdominal Muscle & $\mathrm{Zn}>\mathrm{Cu}>\mathrm{Mn}>\mathrm{As}>\mathrm{Cr}>\mathrm{Pb}>\mathrm{Hg}>\mathrm{Cd}$ \\
\cline { 2 - 3 } & Walking Leg & $\mathrm{Zn}>\mathrm{Mn}>\mathrm{Cu}>\mathrm{As}>\mathrm{Cr}>\mathrm{Hg}>\mathrm{Cd}>\mathrm{Pb}$ \\
\cline { 2 - 3 } & Gill & $\mathrm{Mn}>\mathrm{Cu}>\mathrm{Zn}>\mathrm{As}>\mathrm{Cr}>\mathrm{Pb}>\mathrm{Cd}>\mathrm{Hg}$ \\
\hline $\begin{array}{l}\text { Macrobrachium } \\
\text { nipponense }\end{array}$ & Muscle & $\mathrm{Zn}>\mathrm{Cu}>\mathrm{Mn}>\mathrm{As}>\mathrm{Cr}>\mathrm{Pb}>\mathrm{Cd}>\mathrm{Hg}$ \\
\hline
\end{tabular}


Table 3. Comparison of elemental concentrations ( $\mu \mathrm{g} \mathrm{g}^{-1}$ dry weight) in the muscle tissues of crayfish from the Zhenjiang, City with the other regions

\begin{tabular}{|c|c|c|c|c|c|c|c|c|c|}
\hline Location & Sample & $\mathbf{C u}$ & $\mathbf{Z n}$ & Mn & $\mathrm{Cr}$ & Cd & $\mathbf{P b}$ & $\mathrm{Hg}$ & As \\
\hline Present study & P. clarkii Abdominal Muscle & 17.3 & 95.9 & 16 & 0.714 & 0.0245 & 0.241 & 0.222 & 1.13 \\
\hline Present Study & P. clarkii Waking leg & 18 & 299 & 47.1 & 0.64 & 0.0063 & 0.004 & 0.102 & 1.05 \\
\hline Present Study & P. clarkii Gill & 93.8 & 53.9 & 99.8 & 3.3 & 0.0281 & 2.3 & 0.0076 & 3.8 \\
\hline Present Study & M. nipponense Muscle & 71.8 & 81.7 & 10.6 & 1.2 & 0.0785 & 0.323 & 0.0136 & 2.17 \\
\hline Czech Republic $^{1}$ & P. clarkii Abdominal Muscle & 32.9 & 76.9 & - & 4.2 & 0.05 & $<0.5$ & 1.18 & - \\
\hline Louisiana, USA $^{2}$ & P. clarkii Abdominal Muscle & 31 & 61.6 & - & - & 0.06 & 4.5 & - & $0.2-3.7$ \\
\hline Louisiana, USA ${ }^{2}$ & P. clarkii Gill & 204 & 113 & - & - & 0.23 & 4.2 & - & $0.6-8.7$ \\
\hline Italy $^{3}$ & P. clarkii Abdominal Muscle & 187 & 156 & - & - & 2.4 & 0.9 & - & - \\
\hline Egypt $^{4}$ (wet weight) & P. clarkii Abdominal Muscle & 5.5 & 14.2 & 2.5 & - & 0.23 & 0.9 & - & - \\
\hline Egypt $^{4}$ (wet weight) & P. clarkii Gill & 41.9 & 7.9 & 24.1 & - & 0.273 & 1.02 & - & - \\
\hline Ebro River, Spain ${ }^{5}$ & P. clarkii Abdominal Muscle & $12.1-82.3$ & $49.2-127$ & $1.7-2.6$ & - & $0.03-0.41$ & $0.22-3.1$ & $0.76-1.64$ & $12.1-82.3$ \\
\hline California, USA $^{6}$ & P. clarkii Abdominal Muscle & 44.6 & 76.9 & - & 0.43 & 0.0 & 0.2 & - & 0.7 \\
\hline Spain $^{7}$ & P. clarkii Abdominal Muscle & 28.2 & 65.7 & - & 1.6 & - & 1.1 & - & 0.8 \\
\hline Egypt $^{8}$ & P. clarkii Abdominal Muscle & 32.7 & 125 & - & 5.1 & - & 15.9 & - & - \\
\hline South-Western Sicily, Italy ${ }^{9}$ & P. clarkii Abdominal Muscle & 17.3 & 74.9 & - & 0.81 & 0.0 & 0.2 & - & 1.8 \\
\hline $\mathrm{USA}^{10}$ & P. clarkii Abdominal Muscle & 3.1 & 5.9 & - & 0.5 & - & - & - & - \\
\hline China $^{11}$ & M. nipponense Muscle & 10.7 & 11.7 & - & 0.4 & 0.1 & 0.72 & 0.024 & 0.028 \\
\hline
\end{tabular}

${ }^{1}$ Kuklina et al. (2014), ${ }^{2}$ Gedik et al. (2017), ${ }^{3}$ Goretti et al. (2016), ${ }^{4}$ El-Assal and Abdel-Meguid (2017), ${ }^{5}$ Suárez-Serrano et al. (2010), ${ }^{6}$ Hothem el al. (2007), ${ }^{7}$ Mortimer and Cox (1999)), ${ }^{8}$ Abd-Allah and Abd-Allah (2013), ${ }^{9}$ Bellante et al. (2015), ${ }^{10}$ Madden et al. (1991), ${ }^{11}$ Yi et al. (2011). 
Table 4. Bioaccumulation factors for metals in the crayfish and oriental river prawn.

\begin{tabular}{|l|r|r|r|r|r|r|r|}
\hline Species & \multicolumn{1}{c|}{ Cu } & \multicolumn{1}{c|}{ Zn } & \multicolumn{1}{c|}{ Pb } & \multicolumn{1}{c|}{ Cd } & \multicolumn{1}{c|}{ Cr } & \multicolumn{1}{c|}{ Hg } & \multicolumn{1}{c|}{ As } \\
\hline P. clarkii Abdominal Muscle & 6160 & 3090 & 121 & 61.3 & 549 & 555 & 1160 \\
\hline P. clarkii Waking leg & 6440 & 9650 & 2 & 15.6 & 489 & 255 & 1080 \\
\hline P. clarkii Gill & 33500 & 1740 & 1170 & 70.3 & 2520 & 18.9 & 3880 \\
\hline M. nipponense Muscle & 25600 & 2640 & 162 & 196 & 887 & 33.9 & 2230 \\
\hline
\end{tabular}


Table 5. Estimated daily intakes (EDI $\mu \mathrm{g} \mathrm{kg} \mathrm{body} \mathrm{wt}^{-1}$ day $^{-1}$ wet weight) of metals by consuming crayfish and oriental river prawn

\begin{tabular}{|l|c|c|c|c|c|c|c|c|}
\hline \multicolumn{1}{|c|}{ Species } & Cu & Zn & Mn & Cr & Cd & Pb & Hg & As \\
\hline P. clarkii Abdominal Muscle & 5.7 & 31.7 & 5.3 & 0.2 & 0.0 & 0.1 & 0.1 & 0.4 \\
\hline P. clarkii Waking leg & 5.9 & 98.7 & 15.5 & 0.2 & 0.0 & 0.0 & 0.0 & 0.3 \\
\hline P. clarkii Gill & 30.9 & 17.8 & 32.9 & 1.1 & 0.0 & 0.8 & 0.0 & 1.2 \\
\hline M. nipponense Muscle & 23.7 & 27.0 & 3.5 & 0.4 & 0.0 & 0.1 & 0.0 & 0.7 \\
\hline PTDI & 500 & 1000 & 140 & 3 & 1 & 3.57 & 0.23 & 2.14 \\
\hline
\end{tabular}

PTDI Provisional tolerable daily intake suggested by Joint FAO/WHO committee on Food Additives (JECFA 1999a). The PTDI value of Cr was based on the reference dose (RfD) of Cr (VI) established by US Environmental Protection Agency (2011), For Hg and As adpated from Bhupander and Mukherjee (2011)

Table 6. Maximum Permissible Limit (MPL) of trace metals in fish muscles $\left(\mu \mathrm{g} \mathrm{g}^{-1}\right.$ wet weight) according to National and International Guideline values.

\begin{tabular}{|c|c|c|c|c|c|c|c|c|}
\hline Standard's & $\mathrm{Cu}$ & $\mathrm{Cr}$ & $\mathbf{P b}$ & $\mathbf{C d}$ & $\mathbf{Z n}$ & Mn & $\mathbf{H g}$ & As \\
\hline WHO (1989a) & 30 & 50 & 2 & 1 & 100 & $0.5-1$ & - & \\
\hline CFHC (1994) & 50 & 2 & 0.5 & 0.1 & 50 & - & 0.5 & 0.1 \\
\hline FAO (1983) & 30 & - & 0.5 & 0.5 & 40 & - & 0.5 & 1.4 \\
\hline HKG (1987) & & & & & & & 0.5 & 2.3 \\
\hline USEPA (2000) & 120 & 8 & 4 & 2 & 120 & - & - & \\
\hline EC (2014) & - & - & 0.3 & 0.5 & 30 & - & - & \\
\hline FSSAI (2015) & - & - & 0.3 & 0.3 & - & - & - & \\
\hline
\end{tabular}

WHO-World Health Organization; CFHC -Chinese Food Health Criterion; FAO-Food and Agricultural Organization; HKG-Hong Kong Government regulation; USEPA-United States Environmental Protection Agency;

EC-European Commission; FSSAI - Safety, Food, Standards Authority of India 


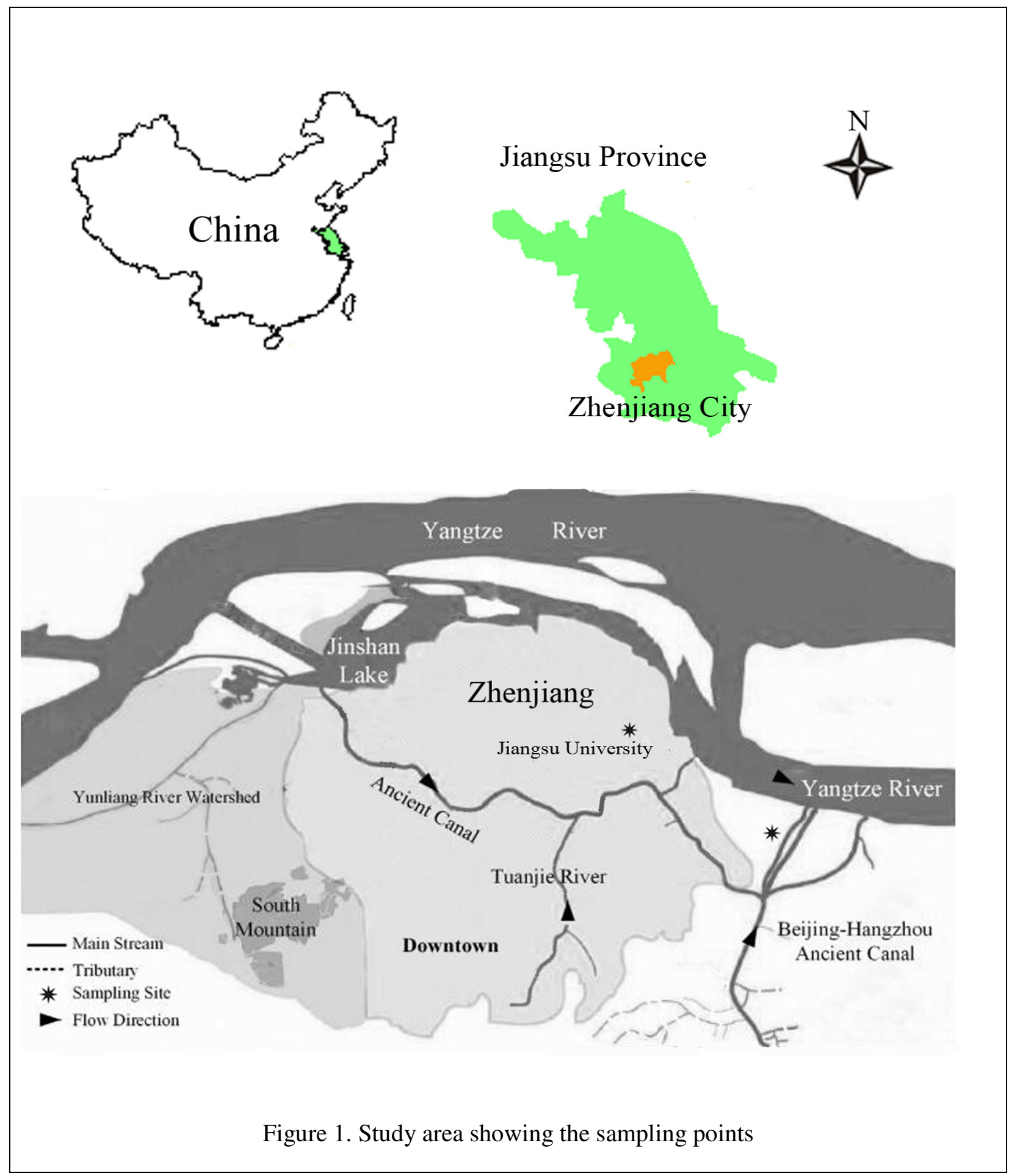

